\title{
Clinical records: the medical writing from the patient's story to the medical narrative
}

\section{Historia clínica: la escritura médica del relato del paciente a la narrativa médica}

\author{
Carlos Alberto Miranda-Bastidas \\ cmirandabastidas@gmail.com
}

Universidad del Valle, Facultad de Salud, Escuela de Medicina. Cali, Colombia

\section{Abstract}

A historical follow-up of the medical writings on patients was carried out, from the Hippocratic texts to the appearance of the current canon of clinical history formulated by Boerhaave in the 17th century, passing through the medieval consilia and the curationes and observationes of the Renaissance. Moreover, how much the patient\&\#39;s account is present in these writings was discussed. It was postulated that the medical narrative starts from adequately listening to patients and their history. It was worked in a literary workshop format that is a pedagogical tool that contributes to comprehensive medical training and offers the possibility for the patient to be treated in an empathetic and humanized environment.

\section{Keywords:}

Medical narrative; medical writing; medical history; clinical case; Hippocrates; consilia; observatio; humanization; observation; medical records; patientcentered care

\section{Palabras clave}

Narrativa médica; escritura médica; historia clínica; caso clínico; Hipócrates; consilia; observatio; humanización; observación; archivos médicos; cuidado centrado en el paciente

\section{Resumen}

Se llevó a cabo un seguimiento histórico de los escritos médicos sobre pacientes, desde los textos hipocráticos hasta la aparición del canon actual de la historia clínica formulado por Boerhaave en el siglo XVII, pasando por las consilias medievales y las curaciones y observaciones del Renacimiento. . Además, se discutió cuánto está presente la cuenta del paciente en estos escritos. Se postuló que la narrativa médica comienza por escuchar adecuadamente a los pacientes y su historia. Fue trabajado en un formato de taller literario que es una herramienta pedagógica que contribuye a la formación médica integral y ofrece la posibilidad de que el paciente sea tratado en un entorno empático y humanizad 


\section{Conflict of interests:}

None

\section{Corresponding author:}

Carlos Alberto Miranda-Bastidas, Universidad del Valle, Cali, Colombia.

e-mail:cmirandabastidas@gmail.com

\section{Introduction}

A verse by the poet Muriel Rukeyser states that "the universe is made of stories, not of atoms" ${ }^{1}$, a powerful metaphor that brings to the fore the human communication capacity based on stories. At the anthropological level, emphasis has been placed on the fact that the first evidences of writing are stories that gather events, beliefs and emotions, which implies the existence of an oral narrative architecture, prior to the irruption of writing. Present not only in writing, but in every communicational or artistic product of first humans, it is spoken, in these terms, of a homo narrans, a cultural predecessor ${ }^{2}$. All human records, even isolated accounting data, for example, carry a narrative background.

Following this line, the patient-doctor encounter turns out to be much more than a healthcare event. It is, among other things, a setting where the story of the sick person -which is a story of the morbid experience that afflicts him or her, full of emotions, autochthonous observations and interpretations, presented in everyday language-, is taken by the doctor, put in another narrative format and converted into a text with a rigid structure and specialized lexicon, regulated by the medical academy. As a result, the oral story is transformed into a written narrative: the clinical history as the most representative product.

Technically, this is how professions work, as Eliot Freidson pointed out in his sociological study on medicine, the claim of authority over the areas of study that they handle implies making their own conception of others' problems, changing the forms and definitions of how these, the profane, conceive or experience them ${ }^{3}$.

In the transition from one story to another that gives rise to the medical history, what the patient tells is reduced to what the doctor "sees". In this subjective vision, the possibility of the patient to be sufficiently represented in writing is summed up. There, it is made explicit that the final text narrates a pathological incident that uses the body of someone vaguely outlined, or that text of testimony of a life event of a specific person suffering from a disease. That patients must be adequately listened to and their narration given the highest importance, is repeated as unappealable clinical slogans in conferences and training texts. "The most important difference between a good and indifferent clinician lies in the amount of attention paid to the story of a patient", said Farquhar Buzzard, renowned Oxford professor ${ }^{4}$.

However, this enthusiastic consideration is limited. Gaspar Bayle, who emphasized the patient's emotional and thinking elements, considering that a doctor should handle psychology with ease, wrote that the clinician "must be on guard against patient's opinions, and sometimes against their assertions, although you should carefully annotate the phenomena that can only be known through your report" ". An alert that, interpreted as convenient, has served to ignore the patient. In a national semiology text, it can be read that "most of the patients start a confusing and full of secondary details story, which if listened to would take up appreciable time", they invite to "interrupt the patient" and make them "concrete" in the account of their "troubles" 6 . It is illustrative how patients are drawn as a source of confusion and waste of time.

The sensible aspect of this topic goes beyond the discussion in terms of humanism, which is the most relevant and where most of the controversies have settled, due to the obviousness that patients cannot be secondary actors in their own condition and must be treated with consideration; but there is also a technical and clinical issue. Anne Marie Chartier, in a text on the analysis of the writing of school notebooks at the beginning of the 20th century, expressed that: "the writing that notebooks show does not rest on the living word of everyday language. On the contrary, it is on what is written that the orality of school is supported, which is not the orality of conversations" 7 . We can make the same appreciation with the clinical history, which regarding medical education represents the "school notebooks" of the formative years, medical orality with respect to the art of treating is based on what is written in the clinical history. It is 
the language in which the contents of the information directed to the patient and their relatives are also built, and that causes that they are who end up assimilating these oral forms and deconstructing their initial account to reconstruct it in the medical verbal forms.

This essay makes a historical follow-up of the presence of the patient's story in the medical writings of western tradition, and of the most relevant genres that were created for this approach. The current situation of the Clinical History is described, considering that nowadays it is unprovided of that narration and has turned more into an administrative instrument than a reference of a sick person. It concludes with a look at medical education strategies to rescue the presence of the patient's voice in therapeutic acts in general and in the records of the medical history. In this sense, it is stated that the formats of "medical narrative" can be useful instruments for teaching medicine.

\section{The patient's narration in clinical history}

Making the medical history is the only compulsory writing exercise that doctors do, both in their student years in clinical rotations and during their professional practice. Doctors record in it the aspects that they consider relevant from what the patient (or the people around him) have told them, which is the part that corresponds to the anamnesis, and includes the data that they obtain from their observation and from the exams performed. This information is used for the analysis that leads to the formulation of the diagnosis, treatment and subsequent follow-up.

The texts on the clinical history published in books and specialized magazines are usually intended to become an elaboration guide, full of paragraphs that highlight the importance of the document, ${ }^{18}$ and others that bring up legal and ethical elements related to the history, but nothing related to the narrative exercise, except for recommendations of clarity and legibility ${ }^{29-11}$.

The construction of the clinical history is a narrative act, both in form, that involves the aspects related to language and grammar that must be applied, and in depth, as it is an episode in a person's life. A patient's story transcends the anecdote of the symptoms and involves their life contexts, generally absent in a typical medical history. The anecdote, on the other hand, is hardly a reference on which the doctor usually turns his capacity of inquiry. Those are the circumstances in which a patient's medical history actually reflects the history of an illness.

Hippocratic records about the patient

The texts that we could call Hippocratic "medical histories"3 gave little room to the patient's account and were written on the experiences of itinerant doctors that made recounts of the patients' evolution..$^{12}$ The anamnesis is absolutely secondary in them. In these narratives of Greek antiquity the doctor's observation is privileged, they are valuable literary, historical and nosological pieces, but the patient as an individual is hardly referenced: "Filisco lived near the wall", "Silenus lived on the platform, near the house of Evalidas ", "Erasino lived next to the ravine of Bootes" ${ }^{13}$.

The observation is systematic and chronological, about Filisco it is written:

"he fell down on bed. On the first day he had an acute fever, he sweated at night in a painful state. On the second day all the symptoms were exacerbated, and in the afternoon, thanks to a small enema, he evacuated favourably; calm night. The third day: in the morning and until noon it seemed that he had run out of fever; but towards the afternoon, an acute fever with sweat; thirsty; his tongue was drying up; emitted black urine; at night in poor condition; did not sleep; completely delirious. On the fourth day all symptoms were exacerbated, black urine; at night in a more benign situation, the urine had better colour..." ${ }^{13}$. 
Clinical records: the medical writing from the patient's story to the medical narrative

The patient's presence is only intuited through the symptoms that they should have verbalized, fundamentally pain, the rest is observation and interpretation; rarely does it give rise to patient's or their acquaintances' speculations. From a "maid" who "was attacked by a violent fever" it was noted that "they said that (this had happened to her) for having eaten a bunch of grapes"; $;$ of a teenager who was also feverish, they said that he was like that "as a result of fatigue, effort and careers that are out of the ordinary" 13 .

Despite the limited surviving documentation, it seems that dialogue with the patient was a matter of controversy in Greek antiquity. There is evidence of theoretical disagreements between the schools of Cos (Hippocratic) and Cnido. A Cos doctor, author of "Regimen in Acute Diseases", complained that the patient was given a lot of voice in the description of the conditions, in a text that has not reached our days, the "Cnidias Sentences": "Even those who are not a doctor could correctly describe such processes, if they were informed of patients' conditions from the lips of patients themselves" ${ }^{12}$.

The Hippocratic seemed to privilege the physician's ability to deduce without the patient's information. Rufus of Ephesus, a Greek physician of the second century, in his treatise Quaestiones Medicinales, considers insufficient the method defended by Hippocrates, according to which a doctor when arriving in a new city knows better the relevant things on his own account than questioning its inhabitants ${ }^{14}$. In fact, Rufus of Ephesus is the most renowned advocate of dialogue with the patient among ancient physicians, and established specific points to ask that included, in addition to the regulars established at the time, the patient's nature (physis), their habits, changes to regular behavior, dreams, diet, tastes and reactions to certain situations ${ }^{14}$. In his text

"On the Interrogation of the Patient", he strongly criticized Callimachus because, "he holds that the physical signs (semeia), in each case, are enough to indicate both the disease and its cause, (...) He considers it superfluous to ask about even the determining causes of a disease, such as the manner of life and the various occupations, or whether the patient happened to be tired or cold when he was attacked. He maintains that the physician has nothing to learn from any of these, if he will but carefully consider the signs occurring in each disease" 15 .

Consilia, the medical genre of the Middle Ages

In the Middle Ages the first medical schools in Europe emerged, and the contradictions and debates that will accompany university medical training arose. The "medical histories" of that time have come down to us through the consilia (advice), medical texts that, after describing a patient's disease, taught how to identify and treat it. Despite referring to an individual case, their intention is not the particular patient, but to advise a way of proceeding in the face of similar cases in the future ${ }^{16}$. The most famous consilia are those made by Arnaldo de Villanova, Taddeo Alderotti and Bartolomeo Montagnana, but in general writing them was a regular practice of doctors of the time with a certain academic prestige; the idea was that they passed from hand to hand among the apprentice doctors ${ }^{5}$. They had a precise literary genre format made up of three parts, a first section where the patient's symptoms were described and a diagnostic and etiological consideration was made; a second part in which suggestions were given for a lifestyle that would help to overcome the disease; and a last section in which the therapeutics to follow and the evolution of the patient with the treatment were described ${ }^{17}$. The consilia evolved and gradually expanded, complexed and became a kind of pathological monograph, a learned and speculative dissertation on a case, written in strict medieval academic language, an academic text that helped the practicing doctor at the bedside of the patient. The patient was diluted even more in the narrations of the consilia because the renowned academics who wrote them in the 15th and 16th centuries did not know the patients they opined about in absentia, these were cases consulted by other doctors ${ }^{17}$, in such a way that the clinical case is hardly an excuse for a specific writing about the disease. 
The medical narrative that had been a matter of "daily surveillance of the sick" in ancient Greece, with the consilia became the scene of doctor's erudition, for the subject it deals with and for the literary forms. Montagnana, more than patients' emotions recorded his own: "The fragile human condition recently showed me a condition of maximum terror and the most fatal accidents," he wrote in his Consilium CVI, in which he argues that the patient of the case has all the conditions that make her susceptible to consumption; "So much so that it will be difficult for her to escape from suffering it." And he undertook an inventory of such characteristics, turning the patient into reliable evidence of his knowledge,

"this woman is extremely emaciated, with thinness perhaps due to an increase in yellow bile, or dryness due to melancholy, or from another cause. Secondly, the colour of her face tends to squalor, (...). Thirdly, and mainly, she has concave eyes, and not from birth, but as a result of a defect in the nutrition of the orbits and the substance of the eye. Fourthly, her temples are excavated, that is, deprived of food, as a result of which they are consumed. Fifthly, the skin on her forehead is taut, with perceptible roughness on its surface. Sixthly, her neck is long and graceful. Seventhly, her whole head feels remarkably warm, (...). Eighthly, sharp, mordicative and excoriative materials flow from her head...".

Observatio, the "case" report

The paradigmatic shifts in philosophical thought, literary forms, and the arts brought about by the Renaissance influenced medical writing. From the 16th to the 17th century there was a significant increase in medical literature genres, along with traditional ones: commentarii, consilia, tractatus, novel titles were found, ${ }^{4}$ that advised of theoretical genres such as contradicentia medica, controversiae or disputationes medicae, doctrinarum differentiae, paradoxa medica; and relatives to practice like curationes, casus, historiae; and specially the observationes and the epistolae medicae, primarily used to describe rare cases ${ }^{18}$.

In the count of texts that may bear the imprint of "Clinical History", among those mentioned, the curationes and the observationes stand out. The former are writings that basically suggest a treatment born from practice, ignoring the doctrine (unlike the consilia). In these it is said that something works, but there is no speculation as to why or how. The curationes kept a narrative record about the patient to whom they alluded ${ }^{18}$. But the quintessential pathographic text is the observatio of which Lain Entralgo thinks is the historical continuation of the consilia; when he speaks about the Renaissance physician François Valleriola, he says that with him "the medieval consilium has resolutely changed into the observatio", ${ }^{5}$ but the question is not so simple, the consilia, as noted above, dealt more with the disease than with the clinical case ${ }^{18}$, which will become the subject of the observationes after a particular journey in cultural history. The observationes are a genre of the late Renaissance and a specific product of humanistic medicine ${ }^{18}$. In them, the patient, hardly a reference to the consilia, re-individualizes itself as in the texts of Greek antiquity.

Three words from the Greek philosophical tradition arrived in sixteenth-century academic Europe, especially collected by the medical field, autopsia (which refers to direct, first-hand experience), phainomena, turned into the neologism phenomena (referring to things such as they are, a word emerged in astronomy) and observation ${ }^{19}$. The final destination of them will be dissimilar, only autopsy is preserved as a word and medical genre, meaning "inspection in corpses". The observatio, which in the 16 th century pertained only to medical slang ${ }^{19}$, will have a generalization in academic fields and especially its plural, observationes, will refer to writings of high intellectual appreciation.

In the medical field, the initial appearance of the observatio was related to observance, a set of rules to follow, that is, the requirement of a specific, ritualized behavior ${ }^{18,19}$. In its use as an observation, the oldest preserved text is Jodocus Lommius's Medicinalium observationum libri tres published in 1560, but it is not yet an individual case record ${ }^{18}$. 
The observatio brought a clinical and biographical description as a medical genre, independent of the comments and reflections, which are left for other sections. In these there was an interest in showing the uncontaminated patient of what is not medical observation, it was done in a careful and coherent narration unlike previous medical genres ${ }^{5}$. There was then, more presence of the sick person but their voice was still mediated by the doctor's technical interpretation. There is a curious observatio because the patient narrates it, for example, Felix Platter, a Swiss doctor from the 16th century, wrote about his experience as a plague patient:

"In 1568, already thirty-one of my age, requested by reason of my medical profession, I moved very frequently to various places, using a disordered and diverse diet; until the last day of March, riding towards a castle near our city (Basel), I was surprised by a sudden cold. An icy wind was blowing, and it was snowing; and I, dressed lightly, because I had suspected nothing, riding a river too deep, got wet and cooled my feet. For this reason, I suffered from chills all day and got cold going home. After dinner I was the victim of yawning and unusual panic, and a chill came over me, followed by preternatural heat at night with a headache. The next day, April 1st, and even with my whole body broken and my limbs as if they had been shaken, I left the house to visit some sick people. Shortly after the meal I had a fever, and all the symptoms of it became apparent. The night was excessively restless. On the third day, intense heat, headache, intense pain on the right side, and immense pain in the region of the back; extreme restlessness. I had myself administered a compound clister..." 5

Johns Hopkins University Professor of History of Medicine, Gianna Pomata documents two epistemic situations in the subsequent evolution of the observationes: firstly, the creation with them of an abundant body of information, which was shared among doctors, forming a network of communication from which the specialized magazines emerged; and secondly, a change from the description of rare cases to the intention of classifying diseases, as exemplified by the writings of Thomas Sydenham ${ }^{18}$, with whom we meet at another time in what will be the "clinical history" type of literature.

Sydenham's writings met two criteria: that medical records collect only what is "seen" in the patient, without "physiological" speculations, and that "an individual" case"' be described, but in terms of whether it is an "' example "of a typical way of getting sick" ${ }^{5}$. Foucault said that Sydenham's lesson was ambiguous, noting that in his texts it is made explicit that in order to know the disease "a doctor must abstract himself from the sick"; and he quotes him to demonstrate it:

"He who describes a disease must take care to distinguish the symptoms that necessarily accompany it, and which are proper to it, from those that are only accidental and fortuitous, such as those that depend on the temperament and age of the patient" ${ }^{20}$.

Modern medicine: The canon of clinical history is born

In the eighteenth century, within a context of hospital reorganization and the establishment of a new statute for the sick, the rise of modern medicine was preceded by research inside the corpses, which made possible a notable paradigmatic change, the location of the pathological organ injury ${ }^{20}$. From the recording of symptoms, an attempt was made to determine the connection of these in vivo with post-mortem findings. Bichat considered that by demonstrating this, the category of "true science" could be achieved for Medicine 5 .

In this scenario, anatomo-clinical medicine was born, and a new medical language arrived. The first modern canon of Clinical History formulated by Herman Boerhaave emerged. In his writings he broke down the three areas that medical examination must contain: inspection, anamnestic interrogation and objective exploration ${ }^{5}$. The interesting thing is that this story was structured before medicine integrated the contents of modern science into its documentary body, so this founding turn of current medicine established the genre in which the episodes of life of a sick person were to be recorded. 
Boerhaave was a unique man, he taught medicine, chemistry and physics at the university. He wrote two extensive pathological stories with the type of inquiry he proposed, and in his texts, he tried to make the patient's presence faithful both in what he told and in the observation the doctor made. In one of them he wrote: "He then tried to tell me of the malady he was suffering, but could not; when he intended to talk, the pain prevented him" ${ }^{21}$. In the other story he told: "With all lucidity and a strong voice, he tells the doctor about the illnesses of the night and lets him know of his imminent danger of death. He begs the doctor to bleed him; And as he refuses, he says to him: So, you let me die?" To which the doctor replies: "Am I allowed to hasten your death?"5 5 . These two fragments refer directly to the patient, although in the first one he does not speak. In the second one, his voice is provided, although it may be controversial.

His books reached the great reading mass that boasted erudition, and Curwen, the character of a Lovecraft novel that meets that profile, has them along with other classics ${ }^{22}$. Boerhaave wrote in a very literary style, and in his medical texts he interacted with whoever read them: "you, my reader," he said; "Think, reader" 5 , he suggested. Forms that would be used years later by Gothic literature.

I take a small fragment that illustrates his writing, from his book "Opera omnia medica", which narrates the disease of the Marquis of Saint-Auban caused by a mediastinal tumor:

"It is worth noting that the patient's voice did not change during that year and a half. Nature had endowed him with a manly baritone voice; and he had cultivated it so much through musical learning that he became a very smooth and skilful singer, and without the slightest difficulty or discomfort he was able to hold his breath incredibly and then emit it for a long time. (...) Thus, not only were his limbs flexible for walking, running and dancing, and his arms light, but his breathing was so constant and vigorous that no signs of fatigue were perceived in him, no damage to the chest and lungs, to the point that it was hardly possible to see another person capable of competing against him in ease of breathing and chest strength" ${ }^{5}$.

The canonical structure welcomed doctors from different currents of clinical thought, even rivals, as evidenced by the review of the clinical records they published. Such is the case of Friedrich Hoffmann, main advocate of iatromechanics, and Georg Ernst Stahl, animist, who maintained a heated "pathophysiological" controversy involving heart rate and fevers ${ }^{23}$. This gave the structure a character of a disciplinary instrument to which sections were gradually added, maintaining the original idea.

Since then, the clinical history will contain the results of a perceptual inquiry that prevails over modesty and hygiene. Foucault wrote: "The sight/touch/hearing trinity defines a perceptual configuration in which the inaccessible illness is tracked down by markers, gauged in depth, drawn to the surface, and projected virtually on the dispersed organs of the corpse." ${ }^{20}$. Taste was already well established as a resource of inquiry, and the ancient civilizations of Egypt and India knew that the urine of people with diabetes was sweet. Thomas Willis put that fact on the European medical scene ${ }^{24}$, thus, testing fluids was regular medical behavior. On the other hand, Morgagni wrote that Valsalva said about his autopsies, that "the serum produced by gangrene is so pungent, (...) that when (...) I tried it, (...) its exaggerated acrimony, (...) it let feel its biting effect on the papillae for a whole day" 5 .

The writing of the clinical history in the 19th century grew in complexity, the improvement of the techniques for the physical examination led to the identification of signs without verbal mediation from the patient: "the right chest cavity resonated well when struck. The left half gave an equally clear sound, except in the region of the heart, where the sound was null, "wrote JeanNicolás Corvisart ${ }^{5}$. The introduction of instruments resized physical examination and signs were put in pre-eminence to symptoms. René Laënnec, inventor of the stethoscope, in the introduction to his classic work wrote that in the thoracic evaluation symptoms such as cough or expectoration are too vague to diagnose, but that mediated auscultation gives details. ${ }^{25}$ The body speaks directly to the doctor. 
Laboratory and diagnostic images came later, as another type of text, to join the narrative of the medical history. the body was gradually invaded by technology to make visible what the doctor could not see. Consequently, doctors gave their authority to the technological instrument, which operates based on a well-informed third party (a witness). In the middle of the last century Jean C. Sournia said that we "observe" the patient "in the same way that we observe the stars or a laboratory experiment" ${ }^{20}$. Increasingly more instrumental sophistication and less presence of the person.

From the end of the 19th century and throughout the 20th century, there were theorizations and proposals for additional sections that fundamentally advocated spaces for the results of new medical research. The development of psychoanalytic theory was an exception, which in terms of apprehending the person in the patient not only strengthened biographical tools, but also added psychological interpretation. Patients were reflected in the clinical history with their voice, with their conscious facts and emotions, and even more with what was hidden for them:

"a psychic act goes through two phases (...) between which is interposed a kind of testing (censorship). In the first phase the psychical act is unconscious and belongs to the system Ucs, ${ }^{6}$ if, on testing, it is rejected by the censorship, it is not allowed to pass into the second phase; it is then said to be 'repressed' and must remain unconscious. If, however, it passes this testing, it enters the second phase and thenceforth belongs to the second system, which we will call the system $\mathrm{Cs}^{20}$. That is, conscience.

Sigmund Freud's clinical cases on which he developed his theoretical body, transcended the medical field and reached interdisciplinary diffusion. The Nobel Prize for Literature Committee considered his writing "literary a very good and natural stylistic art" and was among the candidates for the award in $1936^{27}$. Its mark was barely noticeable in the medical history sections dealing with patient's personal life, but it has persisted with some difficulty in specialized mental health records. The patient's events and emotions have a faithful record in his clinical histories, and even in first person. I extract this excerpt from "The case of the Rat Man":

"«I have decided to tell you something that seems very important to me and that torments me from the beginning, " he replied. And he began to develop, with meticulous extension, the clinical history of his father, who had died nine years ago as a result of emphysema. One night, believing that his father's illness could make a favourable crisis, he asked the doctor when the danger could be considered past. The doctor replied that after forty-eight hours. It did not occur to him that his father could die before that term, and at eleven thirty at night he went to bed to sleep an hour. But when he woke up at one o'clock, a doctor friend told him that his father had just died" 28 .

His observations highlighted characteristics and behaviours:

"Our patient was highly superstitious, although he was a man of keen intelligence and a broad culture and sometimes claimed to ignore such nonsense. He was, therefore, superstitious, and at the same time he was not, thus differentiating himself (...) from the uneducated superstitious who feel perfectly in accordance with their absurd beliefs. (...) This contradictory and oscillating behavior only seemed to me to admit a certain explanation (...) the subject had, with respect to such questions, two different and opposite convictions, and not just an indeterminate opinion. (...) As soon as he came to dominate an obsession, he mocked his credulity, and nothing happened to him that could worry him superstitiously; But as soon as he was under the control of an obsession again ... all sorts of singular casual accidents began to occur to him that supported his superstitious conviction. (...) superstition (...) was that of an educated man who lacked superstitions such as the fear of Fridays, the number 13, etc. But he believed in omens and prophetic dreams" 28 . 
Current medical texts dispense with narratives of yesteryear, and extensive statistical documentation and the technological possibility of studying the patient's abstracted disease have led to the identification of symptomatic and pathophysiological constants on which concepts are established and in which nosological entities acquire material category, independent of its presence in a person. There are echoes of the classic medical narrative forms in "case reports" of specialized magazines, and in the popularization essays that tell stories about patients with rare pathologies ${ }^{7}$.

On the other hand, the clinical history has been transformed into an administrative tool, a document that evidences the performance of the medical act and is a requirement for financial controls in the healthcare sector. The possibility of finding non-somatic aspects that define a person in today's clinical history is low. In current accounts patients are deformed phantoms in which they poorly can recognize themselves.

The business trend has tried to turn the clinical history into a "check list" that facilitates digital parameterization. National regulations established it as follows: "the unique electronic clinical history will be mandatory before December 31, 2013" 29, the deadline expired with the unfinished task.

In this modality a person is just a demographic data; we thus witness a certain fading of the clinical history, when still in semiology classes and in specialized articles it is stated that most of the diagnoses are possible just by consulting a well-prepared history ${ }^{30}$.

\section{Medical narrative: the rescue of the patient's story?}

In the time between the descriptions of Freud's patients and the digital systematization of formats as a clinical history, more than a century passed in which the formalization and development of medical education was carried out in the terms suggested by the Flexner Report. When the American Medical Association advised the new curricular implementation and selected practice scenarios at the beginning of the 20th century, it concluded that outpatient services had poor attendance because, among other situations, incomplete, lowquality medical records were made ${ }^{31}$. Making good medical records became the pervasive requirement in medical education, but despite the intentions, complaints continued without geographic or temporal exception ${ }^{30}$. The Tuning project, which more than ten years ago brought together several medical schools in Latin America, drew up a list of medical "competencies" and put the "ability to write the clinical history" as first ${ }^{32}$. Universities in the United States are less specific at this point in outlining their current medical training goals, since they speak abstractly of the ability to collect and analyse information useful for patient care; but, on the other hand, they emphasize objectives such as ethical behavior, communication skills, critical thinking and compassionate treatment ${ }^{33,34}$.

What is interesting about this is that all the proposed objectives need listening and reading skills and are mediated by the patient's narration. In the curricular scenario that these universities propose, and those that follow them around the world, the patient transcends the clinical history and is installed in every medical act. How to make medical education deliver on those promises has always been controversial terrain. From the beginning of the teaching of modern medicine it was thought that the answer could lie in the approach to the Humanities. Henry Sigeritst created a course with that intention at Johns Hopkins ${ }^{35}$, and at the local level, when the Faculty of Medicine of the Universidad del Valle was founded in 1952, its first dean considered that the way to guarantee comprehensive training was by offering "courses of humanistic nature" ${ }^{36}$. This has been the resource used for many years. As of 2004, 88 of 125 American medical schools gave humanities courses, and 28 of them offered courses specifically on literature or narrative studies ${ }^{37}$. 
The anecdote in which the physician and discreet poet Richard Blackmore asked Sydenham about books that should be read for good medical practice is already a topic of discussion, "read Don Quixote" Sydenham is said to have answered. History has given elementary and learned interpretations. From the one that saw in the statement a contempt for the intellectual world of the time, "the medical science of his time displaced him" wrote Lain Entralgo ${ }^{5}$, to the one that praised the clinical virtue of "Don Quixote": "there are very few doctors who, when describing diseases, bear as much in mind as Cervantes the scientific requirements demanded by the way of tracing the history of a disease," said the doctor and historian Antonio Hernández ${ }^{38}$.

I imagine that the answer was trying to express that medical practice requires getting closer to culture, knowing how to read it. In fact, "Don Quixote" is full of allusions ranging from description and recommendation to irony. There is a remarkable fragment, since it denotes that already in the 17th century prevention was a topic of discussion; Sancho says in a letter to Don Quixote:

"This certain doctor himself says of himself that he does not cure diseases when they exist, but rather prevents them, so that they do not come; and the medicines he uses are diet and more diet, up to putting the person in the dry bones, as if the weakness was not greater than the fever" 39 .

Also relevant is the handling of Don Quixote's last days, which puts the effect of emotions on health first,

"his end came when he least expected it; either because of the melancholy caused by being defeated, or because of the disposition of heaven, which ordered him to do so, a fever that kept him six days in bed took root in him" ${ }^{\prime 3}$.

The idea that through the simple assembly of courses a complex result in behavior is achieved does not sound very coherent in the pedagogical sense. The PRIME project comprised of American medical educators concluded that these courses had never been sufficiently evaluated, but with the conviction that the humanities, ethics, patient-centred exercise, and critical thinking were central to medical education, they suggested a series of guidelines. For example, in relation to what we are dealing with, they postulated that the student had to approach the exercise of making narrative reflections, about the literary stories and those of the patients, seeking to approach perspectives on illness and suffering different from their own, which considered "promotes introspection and empathy" ${ }^{40}$. That exercise is a form of medical narrative.

The term "medical narrative" can involve many strategies; the use in a literary workshop format of patients' life stories and literary texts can be an experience that gives practical teachings beyond theoretical courses. Because humans think, dream, and plan in narrative terms, bringing patients' stories to the clinical stage results in better and more sophisticated listening, to find elements of the patient's discursive depth. It also helps to increase the esteem for patients, to give them a compassionate treatment and to manage the clinical information responding to patients' fears and expectations. In one sentence, it enables a humanized clinical relationship ${ }^{41-44}$. In Roland Barthes's words, "to understand a narration is not only to follow the unraveling of the story, it is also to recognize "stages"(...); reading (listening) a story is not just going from one word to another, it is also going from one level to another" 45 .

I think that knowing the scaffolding behind the narratives involved in the medical act is a good resource for learning and clinical practice. Physicians have always talked about the "case", interpreting and learning it means reading it. In these terms, there is a text in the patient, as Osler suggested ${ }^{46}$, or many as the current hermeneutical philosophers suggest. Stephen L. Daniel, spoke of a text with four levels of meaning, adapting the meaning of medieval writing to medicine: The "literal", referring to the events of illness that happen to the patient; the 
"allegorical", the doctor's interpretation (diagnosis); the "moral", referred to the treatment; and the "mystic", the clinical resolution ${ }^{47}$. Drew Leder suggested four texts: the "experiential", which is the disease in the patient's subjective experience; the "narrative", which refers to the elaboration of the clinical history; the "physical", which is the examination of the patient's body; and the "instrumental", product of diagnostic technologies (laboratory, diagnostic images) ${ }^{48}$. It is a fact that the medical act interprets texts and organizes a narrative with which it not only leaves records but also builds an additional text that permits communication with the patient during the therapeutic process.

Literature as a gateway to compassion and suffering

As an epilogue, after having gone through historical medical writings, finding only the footprint of the patient, we see how literature has built over the years texts that exemplify perspectives that doctors should always keep in mind. This in turn shows the pedagogical value of these stories.

Firstly, the description of diseases provided an original perspective. For this, it is worth reviewing the narration of the plague epidemic that Boccaccio makes in "Decameron", full of aesthetic and testimonial value:

"It did not operate as it had done in the East, where if anyone bled through the nose, it was a clear sign of inevitable death. Instead, at its onset in men and women alike, certain swellings would develop in the groin or under the armpits, some of which would grow like an ordinary apple and others of an egg, some larger and some smaller. The common people called them "gavocccioli", and within a brief space of time, these deadly, so-called "gavoccioli" would begin to spread (...) and would appear at random over the rest of the body. Then, the symptoms of the disease began to change, and many people discovered black or livid blotches on their arms, thighs, and every other part of their bodies, sometimes large and widely scattered, at others times tiny and close together. (...) Against these maladies the advice of doctors and the power of medicine appeared useless and unavailing. Perhaps the nature of the disease was such that no remedy was possible, or the problem lay with those who were treating it, for their number, which had become enormous, included not just qualified doctors, but women as well as men who had never had any training in medicine, and since none of them had any idea what was causing the disease, they could hardly prescribe an appropriate remedy for it. Thus, not only were very few people cured, but in almost every case death occurred within three days after the appearance of the signs we have described, sometimes sooner and sometimes later, and usually without fever or any other accident complication" ${ }^{49}$.

Secondly, the approach to suffering. Because if there is something that differentiates the clinical narrative from the literary one, it is the treatment of suffering; in the former it is a symptom, a fact, which serves the intention of revealing the diagnosis; in the latter it is the centre of the disease. For example, this is expressed in the following paragraph taken from "Crime and Punishment":

"The pale, sombre face lighted up for a moment when his mother and sister entered, but this only gave it a look of more intense suffering, in place of its listless dejection. The light soon died away, but the look of suffering remained, and Zossimov, watching and studying his patient with all the zest of a young doctor beginning to practice, noticed in him no joy at the arrival of his mother and sister, but a sort of bitter, hidden determination to bear another hour or two of inevitable torture. He saw later that almost every word of the following conversation seemed to touch on some sore place and irritate it" ${ }^{50}$.

Thirdly, the manufacture of the doctor's image by the patient: in the effort to maintain the "aseptic" clinical dialogue, and in the claim that the patient has a passive and expectant role, the doctor becomes blind to the fact that he has become the "other" of the patient. In this 
accidental encounter, he becomes part of the patient's narrative, acting as the protagonist of a story that he does not control. Juan Gracia Armendáriz is a writer from Navarra who has gone through two kidney transplant surgeries, transforming his experiences as a patient into literary testimony:

"At twelve the doctor arrives. He is a shy and nervous man, who does not like patient questions either. He announces that if I do not have a fever, in the next few days I will be discharged.

"Don't make a fever," he tells me, as if that were within my powers" 51.

Therefore, we could cite many other perspectives from literature, but let's conclude with something more technical, and more aesthetic: metaphors. Patients make their own configuration of their conditions and cover them with a figurative language that is closer to their emotions. The doctor should find the keys to not only cure an illness but also heal a person. When you get sick you deteriorate much more than an organ, and patients tell us about it. Victor Frankl, the Viennese psychiatrist who was a prisoner of the Nazi regime in Auschwitz and Dachau, recounted in his concentration camp memoirs that the inmates were chronically suffering from edema from malnutrition, trauma, general illness, and that one day he encountered a prisoner whose edema had disappeared, and when asked how this had happened, he replied that he have expelled them from his body crying ${ }^{52}$.

${ }^{1}$ They even have severe calls for attention: "the information obtained from the medical history can have life or death consequences"; "Documenting the medical history can save lives."

${ }^{2}$ The bibliography that illustrates this point is abundant and of different types: books, articles in specialized magazines, guides from government ministries. As an example, I quote some texts in Spanish of regular use in universities.

${ }^{3}$ Giving medical texts written before the modern era the name of "medical history" is strictly an anachronism. In this article, the expression in quotation marks "Medical History" is used as a literary license for pre-modern times.

${ }^{4}$ For example: satyrae medicae y epigrammata medica (linked to philology and literature); decisiones medicae and pandectae medicae (associated with legal genres).

${ }^{5}$ In this paragraph Boerhaave writes what the doctor who was in the patient's agony told him.

${ }^{6} \mathrm{Ucs}$ is Unconscious. Cc is Consciousness.

${ }^{7}$ Oliver Sacks' work is an example in this regard

${ }^{8}$ Buboes

\section{REFERENCES}

1. Rukeyser M. The speed of darkness. En: Rukeyser M. Out of silence: selected poems. Triquarterly Books, Northwestern University Press; 2000. pp 135.

2. Ranke K. Problems of categories in folk prose. Folklore Forum. 1981; 14(1):1-17.

3. Freidson E. Profession of medicine: A study of the sociology of applied knowledge. The University of Chicago Press; 1988. pp XV.

4. Porter R. The greatest benefit to mankind. a medical history of humanity. W. W. Norton \& Company, Inc.; 1998. pp 682.

5. Laín EP. La historia clínica: historia y teoría del relato patográfico. Madrid: Consejo Superior de Investigaciones Científicas; 1950. 
6. Moreno RM. El arte y la ciencia en la anamnesis. Ateneo. 2000; 1(1): 23.

7. Chartier AM, Los cuadernos escolares: ordenar los saberes escribiéndolos. Lectura y Vida. 2009; 30(3): 6-18.

8. Nichol JR, Nelson G. Medical history. StatPearls Publishing; 2020. Disponible en: https://www.ncbi.nlm.nih. gov/books/NBK534249/

9. Stevenson I. La historia clínica. Barcelona: Ediciones Toray; 1974.

10. Guzmán F, Arias CA. La historia clínica: elemento fundamental del acto médico. Rev Colomb Cir. 2012; 27:15-24.

11. Ministerio de Salud. Instructivo de historia clínica. Paraguay: Ministerio de Salud; 2012. disponible en: http:// portal.mspbs.gov.py/digies/wp-content/uploads/2012/01/Instructivo_Historia_Clinica.

12. Alsina J. Los orígenes helénicos de la medicina occidental. Barcelona: Editorial Labor S. A.; 1982. p 19-22.

13. Hipocrates. Tratados Hipocráticos. V Epidemias. Editorial Gredos S. A.; 1989. p 78-

14. Letts M. Rufus of Ephesus and the patient's perspective in medicine. British J Hist Phil. 2014; 22(52): 4-6. Doi: 10.1080/09608788.2014.963504

15. Rufus of Ephesus. On the interrogation of the patient. Disponible en: https://www.aroonchande.com/files/ am/Rufus\%20of\%20Ephesus.pdf

16. Agrimi J, Crisciani C. Les 'consilia' médicaux, Turnhout: Brepols, 1994. citado por Pomata G. Observation Rising: Birth of an Epistemic Genre 1500-1650. En: Daston L, Lunbeck E. Histories of Scientific Observation. The University of Chicago Press; 2011.

17. Crisciani C. Medicine as Queen: The Consilia of Bartolomeo da Montagnana. En Manning G, Klestinec C (eds), Professors, Physicians and Practices in the History of Medicine: Essays in Honor of Nancy Siraisi. Springer International Publishing; 2017.

18. Pomata G. Sharing cases: the observationes in early modern medicine. Early Sci Med. 2010;15(3):193-236. doi: $10.1163 / 157338210 \times 493932$.

19. Pomata G. Observation rising: birth of an epistemic genre, 1500-1650. En: Daston L, Lunbeck E (edits). Histories of Scientific Observation. University of Chicago Press; 2011.

20. Foucault M. El nacimiento de la clínica. Una arqueología de la mirada médica. 13 edición. Siglo XXI editores; 1989.

21. Laqueur TW. Bodies, details, and the humanitarian narrative. En: Hunt $L$ (ed). The new cultural history. University of California Press; 1989. p 183.

22. Lovecraft HP. The case of Charles Dexter Ward; 1928. Disponible en: http://www.hplovecraft.com/writings/ texts/fiction/cdw.aspx

23. De Ceglia FP. Hoffmann and Stahl: Documents and Reflections on the Dispute. History of Universities. 2007; XXII(1): 98-140.

24. Ahmed AM. History of diabetes mellitus. Saudi Med J. 2002; 23: 373-378.

25. Laënnec R. De l'auscultation médiate, ou, Traité du diagnostic des maladies des poumons et du coeur, fondé principalement sur ce nouveau moyen d'exploration, 1819. Disponible en: http://gallica.bnf.fr/ark:/12148/bpt6k987580.pdf

26. Freud S. Lo inconsciente, 1915. En: Freud S. Obras Completas, tomo II. Madrid: Editorial Biblioteca Nueva; 1985. p 2065.

27. Espmark K. El premio nobel de Literatura. Cien años con la misión. Nórdica Libros; 2008. p 236.

28. Freud S. Análisis de un caso de neurosis obsesiva («Caso el Hombre de las ratas»), 1909. En: Freud S. Obras Completas, tomo II. Madrid: Editorial Biblioteca Nueva; 1985. p 1450.

29. Congreso de la Republica. Ley 1438 Por medio de la cual se reforma el Sistema General de Seguridad Social en Salud y se dictan otras disposiciones. artículo 112, parágrafo transitorio. Diario Oficial No. 47.957. Colombia: Congreso de la Republica; 2011. 
30. Moreno RM. El arte y la ciencia en la anamnesis. Ateneo. 2000; 1(1): 22

31. Barzansky B, Perloff JD. Trends in the use of outpatient settings for medical education. En: Barzansky B, Gevitz N. Beyond flexner: Medical Education in the twentieth century. New York: Greenwood Press; 1992. p 131.

32. Beneitone P, Esquetini C, González J, Marty MM, Siufi G, Wagenaar R. Reflexiones y perspectivas de la Educación Superior en América Latina. Informe Final - Proyecto Tuning - América Latina 2004-2007. Bilbao: Publicaciones de la Universidad de Deusto; 2007.

33. Harvard Medical School. 1.08 MD Program Objectives; 2018. disponible en: https://medstudenthandbook. hms.harvard.edu/md-program-objectives

34. Johns Hopkins School of Medicine. Mission Statement and Education Program Objectives; 2019. disponible en: https://www.hopkinsmedicine.org/som/curriculum/genes_to_society/mission.html

35. Sigerist H. Historia y Sociología de la Medicina. Bogotá: Editorial Guadalupe; 1974. p 99-100S

36. Ordóñez LA. La saga de los rectores, III capítulo, Jorge Vergara Delgado. Cali: Universidad del Valle; 2015. disponible en http://comunicaciones.univalle.edu.co/sagarectores/jorge-vergara-delgado.pdf

37. Bleakley A, Browne J, Bligh J. Medical education for the future: identity, power and location. London: Springer Dordrecht Heidelberg; 2011.

38. García BP. La medicina en el quijote y en su entorno En: Schz RJM (ed). La ciencia y el quijote. Barcelona: Drakontos; 2005.

39. Cervantes M. Don Quijote de la Mancha. edición del cuarto centenario. Real Academia Española Asociación de Academias de la Lengua Española; 2004.

40. Doukas DJ, McCullough LB, Wear S. Perspective: medical education in medical ethics and humanities as the foundation for developing medical professionalism. Academic Medicine. 2012; 87(3): 334-341.

41. Charon R. Narrative medicine a model for empathy, reflection, profession, and trust. JAMA. 2001; 286(15):1897-1902

42. Widdershoven $\mathrm{G}$. The story of life: hermeneutic perspectives on the relationship between narrative and life history. En: Lieblich A, Josselson R (eds). The narrative study of lives. London: Sage Publications; 1993.

43. Greenhalgh T, Hurwitz B. Narrative based medicine: why study narrative?. BMJ. 1999; 318(7175):48-50.

44. Hudson JA. Narrative based medicine: narrative in medical ethics. BMJ. 1999; 318(7178): 253-256

45. Barthes R. Introducción al análisis estructural de los relatos. En: Barthes R, Greimas AJ, Bremond C, Gritti J, Morin V, Metz C, et al. Análisis estructural del relato. Buenos Aires: Editorial Tiempo Contemporáneo; 1970.

46. Holloway M, When medicine meets literature. Scientific American. 2005; 292(5): 38-39.

47. Daniel SL. The patient as text: a model of clinical hermeneutics. Theoretical Medicine. 1986; 7: 195-210.

48. Leder D. Clinical interpretation: the hermeneutics of medicine. Theoretical Medicine. 1990; 11: 9-24.

49. Bocaccio G. Decamerón. Ediciones Folio S.A.; 1999.

50. Dostoiewski F. Crimen y Castigo. México, D. F.: Axial/Colofón; 2015.

51. Gracia AJ. Diario del hombre pálido. iBooks Editorial Demipage; 2015. Disponible en: https:/itun.es/co/ TA8P8.I

52. Frankl V. Man\&apos;s search for meaning. Boston: Washington Square Press; 1984. 